\title{
10. Sınıf Öğrencilerinin Kimya Dersi “Doğa ve Kimya” Ünitesi ile İgili Kavramaları ve Bilgi Düzeylerinin İncelenmesi
}

\section{Examination of $10^{\text {th }}$ Grade Students' Conceptions and Knowledge Levels concerning "Nature and Chemistry" Unit of Chemistry Course}

\author{
Olcay GÜNEŞ YAZAR ${ }^{\text {iD }}$, Hasan Celal Güzel Mesleki ve Teknik Anadolu Lisesi, Mustafakemalpaşa, \\ gunesolcay08@gmail.com
}

Canan NAKIBOĞLU , Balıkesir Üniversitesi, Necatibey Eğitim Fakültesi, canan@balikesir.edu.tr

Güneş Yazar, O. ve Nakiboğlu, C. (2021). 10. Sınıf Öğrencilerinin Kimya Dersi “Doğa ve Kimya” Ünitesi ile Illgili Kavramaları ve Bilgi Düzeylerinin İncelenmesi. Batı Anadolu Eğitim Bilimleri Dergisi, 12(2), 611-629.

Öz. 2018 Ortaöğretim Kimya Dersi Öğretim Programında yer alan "doğa ve kimya" ünitesi, çevre ilgili sorunlar, sorunların nedenleri ve bu konuların dayandığı kimyasal temellerin öğretildiği bir ünitelerdir. Bu çalışmada, 10. sınıf öğrencilerinin "doğa ve kimya" ünitesinin öğretilmesinden sonra suyun hayat için önemi, çevre kirliliği ve çevre kirliliğinin azaltılması için alınması gereken önlemler ile ilgili kavramalarının belirlenmesi amaçlanmıştır. Çalışma grubu 2019-2020 eğitim-öğretim yılında 10. sınıfa devam eden 421 öğrenciden oluşmaktadır. Veriler, dört faktörden oluşan "Doğa ve Kimya Ünitesi Başarı Testi" kullanılarak toplanmıştır. Çalışmada, suyun önemini, su tasarrufu ve su kaynakları ile ilgili konularda öğrencilerin kavramaları yüksek düzeydeyken; yumuşak su, suyun özellikleri ve endüstride su kullanımı gibi daha fazla kimya bilgisi gerektiren konularda öğrenci kavramalarının daha düşük olduğu sonucuna ulaşılmışır. Çalışmada ulaşılan diğer bir sonuç, öğrencilerin küresel ısınmaya neden olan gazları tam olarak kavramadıkları ve bu gazları asit yağmuruna neden olan gazlardan tam olarak ayırt edemedikleridir. Son olarak, çevre sorunları için geliştirilen çözüm yollarından en etkili olanı insanların bu sorunlar hakkında bilinçlendirilmesi olacağından, bunun sağlanması için nitelikli bir çevre dersine ortaöğretim programında ayrı bir ders olarak yer verilmesi önerisinde bulunulmuştur.

Anahtar Kelimeler: 10. sınıf öğrencileri, Kimya dersi, Doğa ve kimya ünitesi.

\begin{abstract}
The "nature and chemistry" unit included in the 2018 Secondary School Chemistry Curriculum is the unit in which the environmental issues, the causes of environmental problems, and the chemical foundations of the environmental issues. This study aims to determine the conceptions of 10th-grade students about the importance of water for life, environmental pollution and the measures to be taken for the reduction of environmental pollution after the teaching. The study group consisted of 421 students attending to 10 th grade in the 2019-2020 academic year. The "Nature and Chemistry Unit Achievement Test" with four factors was used to determine the students' conceptions. It was concluded that although the students' conception about the topics concerning daily life such as the importance of water for life, water conservation, and water resources is at a high level, the students' conception of the topics that require theoretical knowledge such as soft water, properties of water and water use in the industry are the weak. Another conclusion reached in the study is that the students do not fully comprehend the gases that cause global warming and cannot distinguish these gases from the gases that cause acid rain. Finally, since the most effective solution to environmental issues will be to raise the awareness of people about these problems, it is suggested that a qualified environment-course should be included as a separate course in the secondary school program.
\end{abstract}

Keywords: $10^{\text {th }}$-grade students, Chemistry course, Nature and chemistry unit. 


\section{Extended Abstract}

Introduction. One of the most important factors in the emergence of environmental problems is people's conscious or unconscious activities. To reduce environmental problems, people must first be made aware of their manner and then be informed and raise awareness about taking responsibility for the environmental issues. For this reason, it is extremely important to provide students with environmental education starting from the primary education level. One of environmental education's goals is to empower people to take environmentally responsible actions (Leeming, Dwyer, \& Bracken 1995; Liu \& Chen, 2019). Having the correct environmental knowledge can also prevent the development of any misconceptions about the subject (Arsal, 2010). There is not any course related to the environment in secondary education curricula in our country, environmental subjects are included in both secondary biology and chemistry course curriculums as either a unit or a subject within a unit. One of these units is the "nature and chemistry" unit in which the environmental knowledge, the causes of environmental problems, and the chemical foundations of the environmental issues.

In line with these explanations, this study aims to determine the conceptions of 10th-grade students who attend different school types about the importance of water for life, environmental pollution and the measures to be taken for the reduction of environmental pollution after the teaching of the "nature and chemistry" unit. Depending on the purpose of the research, answers to the following questions were sought.

1. To what extent do 10th-grade students comprehend the importance of water for life after teaching the "nature and chemistry" unit?

2. To what extent do 10th-grade students comprehend water and soil pollution after teaching the "nature and chemistry" unit?

3. To what extent do 10th-grade students comprehend gas pollutants after teaching the "nature and chemistry" unit?

4. To what extent do 10th-grade students comprehend the measures to be taken to reduce environmental pollution after teaching the "nature and chemistry" unit?

5. What are the knowledge levels of 10th-grade students for the unit "nature and chemistry"?

Method. In this study, the survey method was used. The study group consisted of 421 (221 females and 200 males) 10th-grade students attending different school types in Bursa in the 2019-2020 academic year. The "Nature and Chemistry Unit Achievement Test (NCUAT)" was used to determine the students' conceptions of the unit of "nature and chemistry. Cronbach Alpha values of each factor were between 0.61 and 0.76 , respectively.

Results. To find an answer to the first research question, the answers of the questions in the "water and life" factor in the NCUAT were analyzed. There are seven questions under this factor and these questions are grouped under six themes: the importance of water, soft water, water conservation, water resources, water features, and water use in industry. The arithmetic mean score for all items regarding the importance of water for life was determined as 17.90 and $12.1 \%$ of students answered all questions of this factor correctly.

To find an answer to the second research question, the answers to the questions under the "water and soil pollution" factor in the NCUAT were analyzed. There are four questions under this factor and these questions are grouped under three themes: water pollution, water-soil pollution, and soil pollution. It was determined that the student answer averages for all questions gathered under three themes were above $70 \%$.

To find an answer to the third research, the questions under the factor of "environmental impact of gas pollutants" in the NCUAT were analyzed. There are seven questions under this factor, and these questions are grouped under five themes: the greenhouse effect, acid rain, ozone layer, gas pollutant, and gas polluting effect. It was revealed that the students' conception concerning the greenhouse effect was low and that nearly half of the students (46.1\%) considered "nitrogen" gas as one of the gases that cause the greenhouse effect. 
In order to find an answer to the fourth research question, the answers of the questions under the "reduction of pollution" factor in the NCUAT were analyzed. There are seven questions under this factor and these questions are grouped under four themes: "water pollution, environmental pollution, air pollution, and soil pollution". The arithmetic mean score of the students for all items of the "reduction of pollution" factor was determined as 20.71 and $29.9 \%$ of students answered all questions correctly. The correct answers of just over $80 \%$ of the students to the two questions under the water pollution theme have shown that the students' concepts about the prevention of water pollution are quite high.

Discussion and Conclusion. It was determined that the importance of water for life, water conservation, and water resources were well understood by the students, but the students' conceptions related to soft water, water properties and, water usage in the industry were weak. The students' comprehension was lower in the questions that require technical knowledge and to use their knowledge. Regarding second research question, it was concluded that approximately $80 \%$ of the students understood that substances such as batteries, plastics, detergents, and heavy metals cause water and soil pollution, and again $75 \%$ of them were able to notice the substances that remained in the soil without degradation for a long time. In addition, the average success for water and soil pollution was high. It was concluded that the students do not fully comprehend the gases that cause global warming and cannot fully distinguish the gases that cause acid rain and the gases that cause the greenhouse effect. It was concluded that the students' understanding of acid rain was high, and they only mixed gases that cause acid rain with gases that damage the ozone layer. This situation can be interpreted as a result of not knowing the chemical formulas of the gases.

Since the most effective solution for environmental problems will be to raise the awareness of people about these problems, it has been suggested that a qualified environmental education covering all segments of the society should be included as a separate course in the secondary school curriculum. 


\section{Giriş}

Çevre sorunları oluşumuna neden olan en önemli faktörler, insanların bilinçli ya da bilinçsiz yaptıkları faaliyetlerdir. Bu nedenle çevre ile ilgili sorunların azaltılması için öncelikle insanların davranışlarının farkına varmalarının sağlanması, sonrasında da çevre ile ilgili sorumluluk almaları konusunda bilgilendirilmeleri ve bilinçlendirilmeleri gerekir. Kişilerin çevreye yönelik bilgilendirilme ve bilinçlendirmeleri için de çok küçük yaştan itibaren çevre eğitimi verilmesi son derece önemlidir. Palmer (2003), "çevre eğitimi" terimini tanımlama girişimi ile ilgili tarihindeki en büyük dönüm noktasının 1970 yılında ABD Nevada, Carson City'deki Foresta Enstitüsü'nde düzenlenen Uluslararası Doğa ve Doğal Kaynakları Koruma Birliği (IUCN)/UNESCO "Okul Müfredatında Çevre Eğitimi Uluslararası Çalışma Toplantısı" olduğuna dikkat çekerek, bu toplantıda çevre eğitimi için aşağıdaki klasik tanımın yapıldığını belirtmiştir:

Çevre eğitimi, insan, kültürü ve biyofiziksel çevresi arasındaki karşılıklı ilişkiyi anlamak ve takdir etmek için gerekli beceri ve tutumları geliştirmek için değerleri tanıma ve kavramları netleştirme sürecidir. Çevre eğitimi ayrıca, çevre kalitesi ile ilgili konularda bir davranış kodunun karar vermede ve kendi kendine formüle edilmesinde pratik yapmayı gerektirir (IUCN, 1970 akt. Palmer, 2003, s.7).

Öğrencilerin daha bilinçli olmasını sağlamak adına yapılan çevre eğitimi amaçlarına göre değişiklik gösterse de, yukarıdaki tanımlamaya da dayanarak, bu eğitimi alan kişilerin çevre ile ilgili bilgileri, tutumları ve davranışlarının gelişeceği söylenebilir. İnsanların bilinçli veya bilinçsiz olarak yaptıkları olumsuz davranışlar sonucu ortaya çıkan çevre sorunları herkesi etkilerken diğer taraftan çevreye yönelik olumlu davranışlar çevrenin sürdürülebilirliği üzerine önemli katkılar sağlamaktadır. Bu nedenle ilköğretim seviyesinden itibaren bireylerin çevreye duyarlı olarak yetişmesi, çevrenin sürdürülebilir şekilde kullanımı için son derece önemlidir (Başaran Uğur, Bektaş ve Güneri, 2019). Kişilerin çevreye yönelik olumlu davranışları, onların çevreye yönelik olumlu tutumları ile ilişkili olup burada duyuşsal boyut oldukça önemliyken, duyuşsal boyut kadar önemli diğer bir boyut da kişilerin çevreye yönelik bilgi seviyeleridir. Kişilerin çevre ile ilgili bilgilerinin çevre sorunları ve bu sorunlara yönelik alınacak önlemler gibi konuları içermesi yanında, çevre sorunlarına neden olan olayları anlayacak bilgiye sahip olmaları da gerekir. Çünkü insanlar çevre konularına yönelik bilgi sahibi olduklarında çevre sorunlarına karşı duyarlı hale gelebilirler. Çevre eğitimi alanındaki bazı araştırmalar, çevre sorunları hakkında kapsamlı bilgi düzeyinin çevre dostu davranışlara yol açtığını ve çevreye karşı daha fazla farkındalık ve duyarlılıkla sonuçlandığını belirtmişlerdir (Hungerford ve Volk 1990).

Son yıllarda dünyamızın geleceği ile ilgili oldukça ciddi çevre sorunları, çeşitli haber kaynaklarında daha fazla yer almaya başlamıştır. Bu tür sorunların nedenlerini anlayıp ona göre davranabilmek için öncelikle bilinçli yurttaş olunması gerektiği açıktır. Çünkü bu sorunları çözebilecek kişisel gücümüz olmasa da bu tür sorunların daha fazla büyümesine engel olmak veya çözümün parçası olabilmek adına herkese düşen görevler söz konusudur. Bu görevleri yerine getirmek için, sadece çevreye yönelik olumlu tutum, endişe veya farkındalığa sahip olmak yeterli olmayıp sorunların kaynağının neler olduğu ve çözüm yolları önerebilmeye yönelik temel bilgilere de sahip olunması gerekir. Bu nedenle çevre eğitiminin bir amacı, insanları çevreye karşı sorumlu eylemlerde bulunmaları konusunda güçlendirmesidir (Leeming, Dwyer ve Bracken 1995; Liu ve Chen, 2019). Çevre ile ilgili doğru bilgilere sahip olmak aynı zamanda konuya yönelik herhangi bir yanlış kavrama gelişiminin de önüne geçebilir (Arsal, 2010). Çevreye yönelik bilgiler sadece sınıf içinde değil öğretimin dışında günlük hayatın içinde de edinilir. Günlük hayattan edilen bilgilerin yanlış olma ihtimalleri, sınıf içinde öğretimden edinilenlere oranla daha yüksek olabilir. Bütün bu nedenlerle çevre eğitimi, öğrencilerin çevre konularına yönelik doğru bilgileri edindikleri derslerdir. Diğer taraftan ülkemizde ortaöğretim ders programlarında doğrudan bir çevre dersi bulunmamakla birlikte, 
çevre konuları hem biyoloji hem de kimya dersleri öğretim programlarında bir ünite ya da bir ünitenin içinde konu olarak yer almaktadır. Bu ünitelerden birisi de bu çalışmada ele alınan "Doğa ve Kimya" ünitesidir.

\section{Çevre ile ilgili öğrenci bilgi düzeyi ve kavramalarını inceleyen çalışmalar}

Ülkemizde çevre konularına yönelik öğrencilerin bilgilerini ölçme amaçı gerçekleştirilen çalışmalar incelendiğinde, "doğa ve kimya" ünitesi ile ilgili doğrudan öğrenci başarılarını araştıran bir çalışma olmadığı görülmüştür. Ancak farklı öğretim düzeylerinde çevre bilgilerini ölçen (Atasoy ve Ertürk, 2008) veya bu ünite içinde yer alan önemli çevre sorunlarını ayrı ayrı ele alarak öğrencilerin bu konulara yönelik kavramalarının veya başarılarının incelendiği çalışmaların var olduğu belirlenmiştir. Çevre sorunlarını tek tek ele alan bu çalışmalarda çoğunlukla, sera etkisi, asit yağmurları, ozon tabakası, küresel ısınma ile su ve toprak kirliliği gibi sorunlara ilişkin öğrencilerin kavramaları değerlendirilmiştir. Küresel çevre sorunlarının tek tek ele alındığı çalışmalardan ülkemizde ve uluslararası alanda en fazla çalışılan konuların başında sera etkisi geldiği görülür. Sera etkisi ve buna bağı küresel ısınma ile ilgili yapılan çalışmalar incelendiğinde, her öğrenim kademesinde öğrencilerin bilgi düzeyleri ve yanlış kavramalarının araştırıldığı görülür. Gerek ülkemiz gerekse yurt dışında sera etkisi ve küresel ısınma konularında yürütülen çalışmalarda öğrencilerin önemli yanlış kavramalara sahip oldukları belirlenmiştir (Arsal, 2010; Ayvacı ve Çoruh, 2009; Bahar ve Aydın, 2002; Bakırcı ve Yıldırım, 2017; Boyes, Stanisstreet ve Papantoniou, 1999; Boyes ve Stanisstreet, 1998; Bozkurt ve Cansüngü Koray, 2002; Kınay, Stanisstreet ve Boyes, 2008; Österlind, 2005; Ünlü, Sever ve Akpınar, 2011).

Genel çevre bilgisinin ölçüldüğü çalışmalarda en dikkat çekici nokta, bu çalışmaların ülkemizde ve dünya da ilköğretim düzeyinden üniversite düzeyine, özellikle öğretmen adayları ile yürütülmesi noktasında geniş bir yelpazeye sahip olmasıdır. İlköğretim düzeyinde yürütülen çalışmalardan birinde, Atasoy ve Ertürk (2008), ilköğretim 6. 7. ve 8. sınıf öğrencilerinin çevresel tutum ve bilgilerini birlikte incelemişlerdir. Çalışma sonunda, öğrencilerin çevre bilgisi ve çevre tutumu açısından yeterli düzeyde olmadıkları ve çevre bilgisi ile çevresel tutum puanları arasında çok güçlü olmasa da bir ilişki olduğu belirlenmiştir. İlköğretim düzeyindeki diğer bir çalışmada, Akyol ve Kahyaoğlu (2012), 6, 7 ve 8. Sınıf öğrencileri ile yürüttükleri araştırmada 'Çevre Bilgi Testi' kullanmışlardır. Çalışmada, 6 ile 7. ve 8. sınıf öğrencilerinin çevre bilgi başarı düzeyleri bakımından sınıf düzeyi arttıkça çevre bilgi düzeyinin artmış olduğu ve cinsiyet faktörünün çevre bilgi düzeyi üzerinde etkisinin olmadığı sonucuna ulaşılmıştır.

Üniversite düzeyinde yürütülen çalışmalara bakıldığında, Sadık ve Çakan (2010) biyoloji bölümü öğrencilerinin çevre bilgisi ve çevre sorunlarına yönelik tutumlarını incelemiştir. Çevre Bilgisi Testi ile toplanan verilerin analizi sonucu biyoloji bölümü öğrencilerinin çevre bilgilerinin iyi durumda olduğu sonucuna ulaşmışlardır. Bu durumun öğrencilerin çevre ile yakından ilgisi olan biyoloji öğrencileri ile yürütülmüş olmasının önemi büyüktür. Diğer taraftan diğer alanlardaki öğretmen adayı ve üniversite öğrencileri ile yürütülen çalışmalarda, çevre bilgi düzeylerinin bu kadar yüksek olmadığı gösterilmiştir (Demircioğlu, Demircioğlu ve Yadigaroğlu, 2015; Frick, Kaiser ve Wilson, 2004; Güven, 2013; Pe'er, Goldman ve Yavetz, 2007; Timur ve Yılmaz, 2011; Yılmaz, Morgil, Aktuğ ve Göbekli, 2002).

Timur ve Yılmaz (2011) Türkiye genelinde 10 üniversiteden Fen Bilgisi/Fen ve Teknoloji öğretmen adayının çevre bilgi düzeylerini inceledikleri çalışmada, öğretmen adaylarının çevre bilgi düzeylerinin orta düzeyde olduğu ve cinsiyete göre değişmediği sonucuna ulaşmıştır. Diğer taraftan öğretmen adaylarının çevre bilgisi ile genel akademik ortalamaları ve anne eğitim düzeyi arasında anlamlı bir fark olduğu belirlenmiştir. Bu farklılıklar genel akademik ortalamaları ve anne eğitim seviyesi arttıkça öğretmen adaylarının çevre bilgi seviyelerinin arttı̆̆ı şeklinde yorumlanmıştır. Fen 
bilgisi öğretmen adaylarının çevre sorunlarına yönelik bilgi düzeylerinin belirlenmesine yönelik başka bir çalışmada Güven (2013) bir başarı testi geliştirmiştir. Çalışmasının sonunda öğretmen adaylarının çevre sorunlarına yönelik bilgi düzeylerinin düşük olduğunu belirlemiştir. Demircioğlu ve diğerleri (2015) ise fizik, kimya ve biyoloji öğretmen adaylarının genel çevre bilgileri ve içinde yaşadıkları çevreye karşı bu bilgileri kullanma düzeylerini incelemişlerdir. Uygulanan anketin tümü açısından yapılan değerlendirme sonucunda, öğretmen adaylarının çevreye karşı bilgi ve davranışlarının yeterli düzeyde olmadığı ve çevreye yönelik bilgi ve tutumların, cinsiyet ve alanlarına göre farklılaşmadığı sonucuna ulaşılmıştır.

Uluslararası alanda üniversite ve lise öğrencilerinin genel çevre bilgilerinin belirlenmesine yönelik gerçekleştirilen çalışmalarda da benzer sonuçlara ulaşıldığı görülmektedir. Bu tür çalışmalardan birinde, Kaplowitz ve Levine (2005), ABD'de bir üniversiteye devam eden öğrencilerin çevreye yönelik bilgi düzeyini, çevre bilgisi üzerine yılda iki kez yapılan ulusal bir çalışmanın sonuçlarına göre değerlendirmiştir. Çalışmada, üniversite öğrencilerinin genel halktan daha yüksek düzeyde çevreye yönelik bilgiye sahip olduklarını, ancak bilgi seviyelerinin ortalama olarak yetersiz olduğu sonucuna ulaşmışlardır. Benzer şekilde Gambro ve Switzky (1996), Amerikalı 10. ve 12. Sınıf öğrencilerinin çevreye yönelik bilgilerinin incelendiği çalışma sonucunda, öğrencilerin düşük düzeyde çevresel bilgiye sahip olduğunu belirlemişlerdir. Çevre bilgisi ölçeklerindeki maddeler, öğrencilerin asit yağmuru, sera etkisi ve gelecekteki enerji kaynakları gibi çevresel konuları içermektedir. Çalışma sonunda, öğrencilerin çoğunun çevre sorunları ile ilgili temel gerçekleri fark edebilseler de, önemli bir kısmının çevre sorunları ile ilgili sonuçları anlayamadıkları veya bu tür sorunlara olası çözümler için bilgilerini kullanmadıkları sonucuna ulaşılmıştır.

Buraya kadar yapılan alanyazın taramasından görüldüğü gibi özellikle uluslararası alanda lise öğrencilerine yönelik çalışmalar olsa da ülkemizde çalışmaların çoğunda ya ilköğretim ya da üniversite düzeyinde öğrenim gören öğrencilerin çevreye yönelik bilgi düzeyleri ve kavramalar incelenmiştir. 2018 yılı Kimya Dersi Öğretim Programının 9. sınıfında yer alan "doğa ve kimya” ünitesi öğrencilerin ortaöğretim düzeyinde çevre ve çevreye yönelik sorunların kaynağının neler olduğunun öğretildiği bir ünitedir. Ortaöğretim düzeyinde çevreye yönelik özel bir dersin olmaması bu dersin öğretimini oldukça önemli kılmaktadır. Ortaöğretim biyoloji derslerinde de çevre ile ilgili konular yer alsa da çevre sorunlarının temelinde yatan önemli konular kimya bilgisi gerektirmektedir. Bu durum ortaöğretim öğrencilerinin çevreye yönelik bilgi edinmeleri açısından "doğa ve kimya" ünitesinin önemini ortaya koymaktadır.

\section{Araştırmanın Amacı}

Yukarıdaki açıklamalar doğrultusunda bu çalışmada, farklı okul türlerine devam eden ortaöğretim 10. sınıf öğrencilerinin "doğa ve kimya" ünitesinin öğretiminden sonra, suyun önemi, çevre kirliliği ve çevre kirliliğinin azaltılmasına yönelik alınacak önemler ile ilgili kavramalarının belirlenmesi amaçlanmıştır. Araştırma amacına bağlı olarak aşağıdaki sorulara cevap aranmıştır.

1. "Doğa ve kimya" ünitesinin öğretiminden sonra 10. sınıf öğrencileri suyun hayat için önemini ne derece kavrayabilmişlerdir?

2. "Doğa ve kimya" ünitesinin öğretiminden sonra 10. sınıf öğrencileri su ve toprak kirliliğini ne derece kavrayabilmişlerdir?

3. "Doğa ve kimya” ünitesinin öğretiminden sonra 10. sınıf öğrencileri gaz kirleticileri ne derece kavrayabilmişlerdir?

4. "Doğa ve kimya" ünitesinin öğretiminden sonra 10. sınıf öğrencileri çevre kirliliğinin azaltılması için alınacak önlemleri ne derece kavrayabilmişlerdir?

5. “Doğa ve kimya” ünitesine yönelik 10. sınıf öğrencilerinin bilgi düzeylerini nasıldır? 


\section{Yöntem}

Bu çalışmada, nicel araştırma yöntemlerinden tarama modeli kullanılmıştır. Tarama araştırması, belirli grubun bazı özelliklerini belirlemek için verileri toplama çalışmasıdır (Büyüköztürk, Kılıç Çakmak, Akgün, Karadeniz ve Demirel, 2017). Çalışmanın bu kısımda çalışmanın evren ve örneklemi, araştırmada kullanılan veri toplama aracı ve veri analiz yöntemi ile ilgili bilgiye yer verilmiştir.

\section{Evren ve örneklem}

Çalışmanın evrenini Bursa ilinin bir ilçesinde Fen Lisesi, Anadolu Lisesi, Mesleki ve Teknik Anadolu Lisesi ve Anadolu İmam Hatip liselerinde öğrenim gören 10. sınıf öğrencileri, örneklemini ise bu evreden 2019-2020 eğitim öğretim yılında seçilen 221'i kadın, 200'ü erkek toplam 421 öğrenci oluşturmaktadır. "Doğa ve kimya" ünitesi, 9. sınıfın en son ünitesi olması nedeniyle, çalışmanın örneklemi 10. sınıf öğrencilerden oluşturulmuş ve veri 10. sınıfın ilk haftalarında toplanmıştır. Örneklem, amaçsal örneklemeden maksimum çeşitlilik örnekleme dikkate alınarak belirlenmiştir. Amaçsal örnekleme, kendi içinde benzeşik farklı durumlar belirlenerek yapılan örnekleme olup, maksimum çeşitlilik örneklemede, incelenen problemle ilgili, kendi içinde benzeşik farklı durumların belirlenerek çalışmanın bu durumlar üzerinde yapılması olarak tanımlar (Büyüköztürk ve diğerleri, 2017). Bu amaçla, farklı okul türlerinin çalışmada yer almasına dikkat edilmiştir ve her okul türündeki öğrenci sayııının yaklaşık \%10-12 olacak şekilde öğrenci katılımı sağlanmıştır. Toplam örneklemde kadın ve erkek sayısı birbirine yakın tutulmaya çalışılmıştır. Örneklemde yer alan öğrencilerin okul türü ve cinsiyete göre frekans ve yüzde dağııımları Tablo 1 'de verilmiştir.

Tablo 1.

Öğrencilerin cinsiyet ve okul türüne göre dağılımı

\begin{tabular}{|c|c|c|c|}
\hline Okul Türü & Cinsiyet & $\begin{array}{r}\text { Frekans } \\
(f)\end{array}$ & $\begin{array}{r}\text { Yüzde } \\
(\%)\end{array}$ \\
\hline \multirow{2}{*}{ Fen Lisesi } & Kadın & 58 & 14 \\
\hline & Erkek & 25 & 6 \\
\hline \multirow{2}{*}{ Anadolu Lisesi } & Kadın & 87 & 21 \\
\hline & Erkek & 68 & 16 \\
\hline \multirow{2}{*}{ Mesleki ve Teknik Anadolu Lisesi } & Kadın & 36 & 9 \\
\hline & Erkek & 59 & 14 \\
\hline \multirow{3}{*}{ Anadolu İmam Hatip Lisesi } & Kadın & 40 & 9 \\
\hline & Erkek & 48 & 11 \\
\hline & Kadın & 221 & 52 \\
\hline \multirow[t]{2}{*}{ Örneklem } & Erkek & 200 & 48 \\
\hline & Toplam & 421 & 100 \\
\hline
\end{tabular}

Tablo 1'den görüldüğü gibi örneklemde dört farklı okul türü yer almakta olup örneklemin $\% 52$ 'si kadın ve \%48'i erkek öğrencilerden oluşmaktadır.

\section{Veri toplama aracı}

Araştırma kapsamında öğrencilerin "doğa ve kimya" ünitesine yönelik kavramalarının belirlemesi amacıyla Güneş Yazar ve Nakiboğlu (2019) tarafından geliştirilen ve 25 sorudan oluşan çoktan seçmeli "Doğa ve Kimya Ünitesi Başarı Testi (DKÜBT)" kullanılmıştır. Araştırmacılar DKÜBT'ün dört faktörden oluştuğunu belirlemiş olup bu faktörler "su ve hayat", "su ve toprak kirliliği", "gaz kirleticilerinin çevreye etkisi" ve "kirliliğin azaltılması" şeklinde isimlendirilmiştir. Testin Cronbach 
Alpha güvenirlik katsayısı 0,886 olarak hesaplanmış olup her bir faktöre ait güvenirlik katsayıları faktörler için sırasıyla $0,61,0,66,0,66$ ve 0,76 olarak belirlenmiştir. Testin pilot çalışmasından sonra, yapılan yeni uygulamaya ait bulguların kavrama düzeylerine göre analizine ait veriler bu çalışma kapsamında değerlendirilmiştir.

i̇şlem

Çalışmanın yürütülmesinde Balıkesir Üniversitesi Fen ve Mühendislik Etik Kurulundan etik kural izni ve Bursa III Milli Eğitim Müdürlügünden uygulama izni alınmıştır. Uygulama aşamasında, öğrencilere testin içeriği ve uygulama amacı hakkında bilgi verilerek test verilerinin sadece araştırma amacıyla kullanılacağı açıklanmıştır. Ayrıca test kâğıtlarına isim yazma ve çalışmaya katılma zorunluluğu olmadığını belirten onam formu okutularak imzalatılmıs ve sadece gönüllü öğrenciler çalışmaya dâhil edilmiştir.

\section{Verilerin analizi}

$\mathrm{Bu}$ çalışmada DKÜBT'ün verilerinin betimsel analizi SPSS 22,0 programı kullanılarak yapılmıştır. İlk dört araştırma sorusu ve öğrenci kavramlarının belirlenmesi amacıyla sonuçlar her bir faktör için frekans ve yüzde şeklinde tablolaştırılarak ayrı ayrı sunulmuştur. Kodlayıcı güvenirliğini sağlamak için veri girişi yapan araştırmacı rastgele seçilen 10 öğrenciye ait testi tekrar girerek sonuçları kontrol etmiştir. Ayrıca beş öğrenciye ait rastgele seçilen testin iki yazar tarafından karşılaştırması yapılmıştır ve \%100 uyumlu çıkması sonucu kodlayıcı güvenirliğinin sağlandığına karar verilmiştir.

"Doğa ve kimya" ünitesine yönelik 10. sınıf öğrencilerinin bilgi düzeylerinin nasıl olduğuna yönelik beşinci araştırma sorusuna cevap bulabilmek için McBeth, Hungerford, Marcinkowski, Volk ve Meyers (2008) tarafından geliştirilen Timur ve Yılmaz (2011) tarafında da kullanılan bilgi düzeyi modeli kullanılmıştır. Bu modelde çevre bilgisi düşük, orta ve yüksek şeklinde üç düzeye ayrılmıştır. "Doğa ve kimya" ünitesine yönelik hazırlanan DKÜBT'den alınacak en yüksek puanın 100 olması nedeniyle, bu modelde kullanılan seviyelere benzer şekilde oranlama yapıldığında, "doğa ve kimya" ünitesine yönelik bilgi düzeyi 0-33 puan arası düşük, 34-67 puan arası orta ve 68-100 puan arası yüksek düzey olarak belirlenmiştir. Beşinci araştırma sorusu için analiz bu şekilde yapıldıktan sonra tablolaştırılarak sunulmuştur.

\section{Bulgular}

Araştırmanın sonucunda elde edilen bulgular, araştırma sorulara cevap oluşturacak şekilde ayrı başlıklar altında aşağıda sunulmuştur.

\section{Birinci araştırma sorusuna ait bulgular}

Birinci araştırma sorusunda, "doğa ve kimya" ünitesinin öğretimden sonra öğrencilerin suyun hayat için önemini ne derece kavrayabildiklerine yanıt aranmıştır. Bu amaçla, DKÜBT de yer alan "su ve hayat" faktöründeki sorulara öğrencilerin verdiği cevaplar analiz edilmiştir. Bu faktör altında yedi soru yer almakta olup bu sorular "suyun önemi, yumuşak su, su tasarrufu, su kaynakları, su özellikleri ve endüstride su kullanımı" olmak üzere altı tema altında toplanmaktadır. Bu temalarda yer alan soruların analizine ait bulgular Tablo 2' de verilmiştir. 
Tablo 2 .

10. sınıf öğrencilerinin "su ve hayat" ile ilgili sorular, soruların teması ve cevapların dağılımı

\begin{tabular}{|c|c|c|c|c|c|c|c|c|c|c|c|c|c|}
\hline \multirow{3}{*}{$\begin{array}{r}\text { Soru } \\
\text { No }\end{array}$} & \multicolumn{13}{|c|}{ Şıklar } \\
\hline & \multirow[t]{2}{*}{ Soru Teması } & \multicolumn{2}{|c|}{ a } & \multicolumn{2}{|c|}{ b } & \multicolumn{2}{|c|}{ C } & \multicolumn{2}{|c|}{ d } & \multicolumn{2}{|c|}{ e } & \multicolumn{2}{|c|}{ Boş } \\
\hline & & $f$ & $\%$ & $f$ & $\%$ & $f$ & $\%$ & $f$ & $\%$ & $f$ & $\%$ & $f$ & $\%$ \\
\hline 1 & Suyun önemi & 21 & 5,0 & 16 & 3,8 & 10 & 2,4 & 18 & 4,3 & 352 & 83,6 & 4 & 1,0 \\
\hline 2 & Yumuşak su & 58 & 13,8 & 212 & 50,4 & 51 & 12,1 & 23 & 5,5 & 56 & 13,3 & 21 & 5,0 \\
\hline 4 & Su tasarrufu & 15 & 3,6 & 16 & 3,8 & 14 & 3,3 & 22 & 5,2 & 351 & 83,4 & 3 & 0,7 \\
\hline 5 & Yumuşak su & 45 & 10,7 & 193 & 45,8 & 45 & 10,7 & 37 & 8,8 & 61 & 14,5 & 40 & 9,5 \\
\hline 6 & Su kaynakları & 29 & 6,9 & 15 & 3,6 & 31 & 7,4 & 18 & 4,3 & 327 & 77,7 & 1 & 0,2 \\
\hline 7 & Su özellikleri & 21 & 7,4 & 58 & 13,8 & 242 & 57,5 & 54 & 12,8 & 28 & 6,7 & 8 & 1,9 \\
\hline 15 & $\begin{array}{l}\text { Endüstride su } \\
\text { kullanımı }\end{array}$ & 32 & 7,6 & 25 & 5,9 & 211 & 50,1 & 75 & 17,8 & 55 & 13,1 & 23 & 5,5 \\
\hline
\end{tabular}

Tablo 2 incelendiğinde, "su ve hayat" faktörü altında yer alan sorulardan birinci soruda suyun insanlar için önemi ile ilgili öğrencilerin kavramaları incelenmiştir. Bu soru için öğrencilere suyun üç önemli görevi olan, sindirim ve emilim işlevindeki görevi, vücut ısısını dengeleme görevi ile iç organlardaki zarların ve iskelet sistemindeki eklemlerin kayganlığını sağlayarak hareketi kolaylaştırma görevleri verilerek hangilerinin suyun insanlar için önemli olduğu sorulmuştur. Bu sorunun doğru cevabı olarak öğrencilerden "hepsi" şıkkını seçmeleri beklenmekte olup öğrencilerim \%83,6'sı bu soruyu doğru olarak cevaplamıştır. "Su ve hayat" faktörü altında yer alan ikinci ve beşinci sorular yumuşak suyun günlük hayattaki işlevlerine yönelik olup bunlardan ikinci soruya öğrencilerin $\% 50,4^{\prime}$ ü doğru cevap verirken, beşinci soruya da $\% 45,8$ 'i doğru cevap vermiştir. İkinci soruda yumuşak suyun özellikleri ile ilgili bazı ifadeler verilerek bunlardan hangisinin yanlış olduğu sorulmuştur. İkinci soruya verilen cevaplar incelendiğinde, öğrencilerin \%50,4'ünün deniz ve göl sularının yumuşak su olmadığının farkında oldukları görülmektedir. Ancak öğrencilerin $\% 13,8^{\prime}$ i "yumuşak sularla el yıkarken sabunun elden giderilmediği hissedilir." ifadesine ve \%13,3'ü "iç̧imi hoştur." ifadesine, \%12,1'inin de " $\mathrm{Mg}^{2+}$ ve $\mathrm{Ca}^{2+}$ iyonları derişimi azdır." ifadesine ve \%5,5'i "Isıtıldığı kapta daha az tortu bırakır." ifadesine yanlış dedikleri görülmektedir. Yumuşak suyun özelliklerinin farklı şekilde sorulduğu ve öğrencilerin yumuşak su ile kavramalarının ortaya çıkarılmaya çalışıldığı beşinci soruya verilen cevaplar incelendiğinde, öğrencilerin \%45,8'i "Yumuşak sularda kalsiyum ve magnezyum iyonları derişimi fazladır." ifadesinin yanlış olduğunu belirlemişlerdir. Ancak \%14,5'i "Yumuşak su kullanılan çamaşır ve bulaşık makinelerdeki ısıtıcı bölümlerinin ömrü uzun, makinelerin enerji tüketimi az olur." ifadesine, "\%10,7'si "Sabunlar yumuşak sularda daha iyi köpürür." ifadesine, \%10,7'si de "Yumuşak suyun içim lezzeti daha iyidir." ifadesine ve \%8,8'i "Yumuşak sularda daha az kireçlenme olduğu için sıcak su kullanıldığında zarar daha azdır." ifadesine yanlış dedikleri görülmektedir.

"Su ve hayat" faktörü altında yer alan dördüncü soruda su tasarrufu ile ilgili öğrencilerin kavramaları incelenmiştir. Bu soru için öğrencilere "Diş fırçalarken, tıraş olurken ve el yıkarken musluklar sürekli açık tutulmamalıdır.", "Bozuk musluklar tamir edilmelidir.", "Tarım arazilerini sulamada salma sulama yerine damlama sulama yapılmalıdır." ve "Atık sular arıtılarak uygun yerlerde kullanılmalıdır." şeklinde dört önemli su tasarrufu ifadesi verilerek hangilerinin doğru olduğu sorulmuştur. Bu sorunun bütün ifadelerinin su tasarrufu ile ilgili olduğuna yönelik doğru seçeneğin öğrencilerin \%83,4'ü tarafından seçildiği belirlenmiştir. Öğrencilerin yeryüzündeki su kaynakları ile ilgili kavramalarını belirlemek amacıyla hazırlanan altıncı soruda öğrencilere dört tane su kaynağı (yeraltı suları, kar ve buzullar, deniz ve okyanuslar ile akarsular ve göller) verilerek, bunlardan hangilerinin yeryüzünde su kaynağı olduğu sorulmuştur. Öğrencilerin \%77,7'si verilen 4 kaynağın da yeryüzündeki su kaynağı olduğunu belirten doğru şıkkı seçtikleri görülmektedir. Su özellikleri ile ilgili yedinci soruda öğrencilere "Tarım arazilerinin sulanmasında tuzlu su kullanılır.", "Dünyadaki suyun büyük bir kısmı tatlı sudur." ve "Yeryüzündeki sular sürekli bir döngü içerisindedir." şeklinde verilen üç maddeden hangi ve hangilerinin yanlış olduğu sorulmuştur. Doğru cevap olan ilk iki ifadenin yanlış 
olduğu "b" şıkkı öğrencilerin \%57,5'i tarafından seçilirken, doğru olan üçüncü ifadenin yer aldığı "d" şıkkı öğrencilerin \%6,7'si ve "e" şıkkı öğrencilerin \%1,9'u tarafından seçilmiştir.

"Su ve hayat" faktörü altındaki son soru olan 15. soruda, öğrencilerin endüstride su kullanımı ile ilgili kavramaları incelenmiştir. Öğrencilerden verilen şıklardan hangisi endüstride suyun kullanım alanlarından olmadığı sorulmuştur. Doğru cevap olan "korozyon" öğrencilerin \%50,1'i tarafından seçilmiştir. Bu soruya en fazla yanlış verilen cevaplardan ilki "suyun taşıma maddesi olduğu" ile ilgili şık olup öğrencilerin $\% 17,8^{\prime}$ inin bu şıkkı seçtiği görülmüştür. İkinci en fazla yanlış olarak seçilen ifadeden öğrencilerin $\% 13,1$ 'inin suyun su buharı şeklinde enerji kaynağı olarak endüstriyel kullanımını bilmedikleri görülmektedir.

"Su ve hayat" faktörü için ortalama başarı ile burada yer alan yedi sorunun $(1,2,4,5,6,7,15)$ tamamına öğrencilerin ne kadarının doğru cevap verdiğine yönelik bir analiz yapılmıştır. Testtin toplamı için alınan puan 100 olması durumunda $(25 \times 4)$, bu faktörden alınabilecek maksimum puan 28 (7x4) olup, öğrencilerin faktördeki tüm maddelere yönelik başarı ortalaması 17,90 olarak belirlenmiştir. Ayrıca "su ve hayat" faktöründe yer alan bütün soruları doğru olarak cevaplayan öğrenci sayısının 51 olduğu belirlenmiştir. Bu sayı bütün öğrencilerin \%12,1'ine karşılık gelmektedir.

\section{ikinci Araştırma Sorusuna ait Bulgular}

İkinci araştırma sorusunda, "doğa ve kimya" ünitesinin öğretimden sonra öğrencilerin su ve toprak kirliliğini ne derece kavrayabildiklerine yanıt aranmıştır. Bu amaçla, DKÜBT de yer alan "su ve toprak kirliliği" faktörü altındaki sorulara öğrencilerin verdiği yanıtlar analiz edilmiştir. Bu faktör altında dört soru yer almakta olup bu sorular "su kirliliği, su-toprak kirliliği ve toprak kirliliği" olmak üzere üç tema altında toplanmaktadır. Bu temalarda yer alan soruların analizine ait bulgular Tablo 3 'te verilmiştir.

Tablo 3.

10. sınıf öğrencilerinin "su ve toprak kirliliği" ile ilgili sorulara verilen cevapların

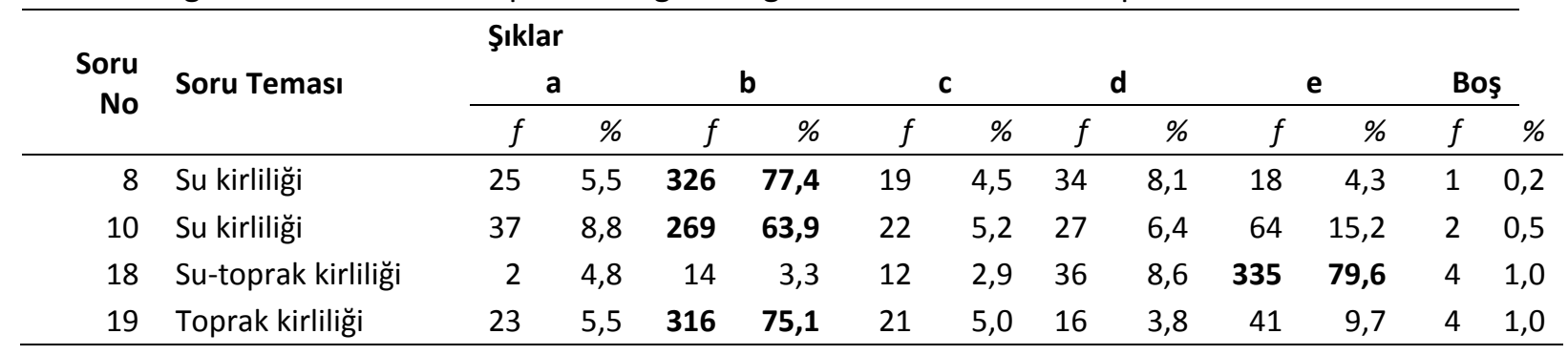

Tablo 3'ten görüldüğü gibi, "su ve toprak kirliliği" faktörü altında yer alan 4 sorudan, sekiz ve onuncu sorular "su kirliliği" ile ilgiliyken 18. soru "su-toprak kirliliği" ve 19. soru da "toprak kirliliği" ile ilgilidir. Sekizinci soruda su kirliliğine etkisi en az olan durumlara yönelik öğrencilerin kavramlarını belirlemek amacıyla, beş tane su kirliliği etkisi (şehirleşme, doğal gübreler, sanayileşme, nüfus artışı ve tarım ilaçları) verilerek, bunlardan hangilerinin su kirliliğine etkisinin en az olduğu sorulmuştur. Bu sorunun doğru cevabı olan "doğal gübreler" seçeneği, öğrencilerin \%77,4'ü tarafından seçilirken, diğer şıkların hepsinin öğrenciler tarafından \%10'un altında seçildiği görülmüştür. Su kirliliği ile ilgili onuncu soruda su kirliliğine neden olan etmenler konusunda öğrencilerin kavramalarını belirlemek amacıyla bazı ifadeler verilerek bu ifadelerden hangisinin su kirliliğine neden olan etmenler arasında yer almadığı sorulmuştur. Bu sorunun doğru cevabı olan "Organik beslenmede artış." ile "Endüstriyel atıkların geri dönüşümü" ifadelerinin öğrencilerin \%63,9'u tarafından seçildiği belirlenmiştir. Bu soruda en fazla yanlış seçilen şıkkın \%15,2 ile "e" şıkkı olduğu görülürken diğer şıkları seçen öğrencilerin oranı ise $\% 10$ 'un altındadır. 
Su ve toprak kirliliğinin birlikte sorgulandığı on sekizinci soruda, su ve toprağa karışması durumunda kirliliğe neden olabilecek bazı maddeler verilerek, öğrencilerden bunlardan su ve toprağa zarar verenleri seçmeleri istenmiştir. Bu sorunun doğru cevabında öğrencilerden beklenen "piller, plastikler, deterjanlar ve ağır metaller" şeklinde verilen bütün maddelerin su ve toprak kirliliğine neden olabileceğini belirleyebilmeleridir. Analiz sonucu, öğrencilerin $\% 79,6$ 'sı tarafından doğru cevabın verildiği ve diğer şıkların hepsinin \%10'unun altında kaldığı belirlenmiştir. Öğrencilerden toprakta uzun süre bozunmadan kalan maddeler konusunda kavramalarının araştırıldığı on dokuzuncu soruda "plastikler, bitki ve hayvan atıkları, ağır metaller, piller ve deterjanlar" seçenek olarak verilmiştir. Öğrencilerden \%75,1'i doğru şık olan "bitki ve hayvan atıkları" şıkkını işaretlemiştir. Bu soru için de diğer şıklara verilen cevapların \%10'un altında olduğu Tablo 3'den görülmektedir.

"Su ve toprak kirliliği" faktörü için ortalama başarı ile faktör de yer alan dört sorunun $(8,10$, $18,19)$ hepsini öğrencilerin ne kadarının doğru cevap verdiğine yönelik bir analiz yapılmıştır. Testtin toplamı için alınan puan 100 olması durumunda, bu faktörden alınabilecek maksimum puan 16 olup, öğrencilerin faktördeki tüm maddelere yönelik başarı ortalaması 11,88 olarak belirlenmiştir. 421 öğrenciden 96 'sı yani öğrencilerin $\% 46,6$ 'sı "su ve toprak kirliliği" faktöründe yer alan bütün soruları doğru olarak cevapladığı bulunmuştur.

\section{Üçüncü araştırma sorusuna ait bulgular}

"Doğa ve kimya" ünitesinin öğretiminden sonra öğrencilerin gaz kirleticileri ne derece kavrayabildiklerine yönelik üçüncü araştırma sorusuna cevap bulabilmek için DKÜBT de yer alan "gaz kirleticilerin çevreye etkisi" faktörü altında yer alan sorular analiz edilmiştir. Bu faktör altında yedi soru yer almakta olup bu sorular "sera etkisi, asit yağmurları, ozon tabakası, gaz kirletici ve gaz kirletici etkisi" olmak üzere beş tema altında toplanmaktadır. Bu temalarda yer alan soruların analizine ait bulgular Tablo 4' de verilmiştir.

Tablo 4

10. sınıf öğrencilerinin "gaz kirleticilerin çevreye etkisi" ile ilgili sorulara verilen cevapların dağııımı

\begin{tabular}{|c|c|c|c|c|c|c|c|c|c|c|c|c|c|}
\hline \multirow{3}{*}{$\begin{array}{r}\text { Soru } \\
\text { No }\end{array}$} & \multirow{3}{*}{ Soru Teması } & \multicolumn{12}{|c|}{ Şıklar } \\
\hline & & \multicolumn{2}{|r|}{$\mathbf{a}$} & \multicolumn{2}{|r|}{ b } & \multicolumn{2}{|r|}{ c } & \multicolumn{2}{|r|}{ d } & \multicolumn{2}{|r|}{ e } & \multicolumn{2}{|c|}{ Boş } \\
\hline & & $f$ & $\%$ & $f$ & $\%$ & $f$ & $\%$ & $f$ & $\%$ & $f$ & $\%$ & $f$ & $\%$ \\
\hline 11 & Sera etkisi & 194 & 46,1 & 28 & 6,7 & 34 & 8,1 & 127 & 30,2 & 29 & 6,9 & 9 & 2,1 \\
\hline 13 & Asit yağmurları & 25 & 5,9 & 22 & 5,2 & 22 & 5,2 & 34 & 8,1 & 317 & 75,3 & 1 & 0,2 \\
\hline 14 & Sera etkisi & 46 & 10,9 & 49 & 11,6 & 33 & 7,8 & 189 & 44,9 & 88 & 20,9 & 16 & 3,8 \\
\hline 16 & Ozon tabakası & 362 & 86 & 16 & 3,8 & 16 & 3,8 & 7 & 1,7 & 19 & 4,5 & 1 & 0,2 \\
\hline 17 & Asit yağmurları & 16 & 3,8 & 285 & 67,7 & 25 & 5,9 & 40 & 9,5 & 45 & 10,7 & 10 & 2,4 \\
\hline 20 & Gaz kirletici & 28 & 6,7 & 27 & 6,4 & 64 & 15,2 & 46 & 10,9 & 242 & 57,5 & 14 & 3,3 \\
\hline 24 & Gaz kirletici etkisi & 92 & 21,9 & 55 & 13,1 & 50 & 11,9 & 45 & 10,7 & 161 & 38,2 & 18 & 4,3 \\
\hline
\end{tabular}

"Gaz kirleticilerin çevreye etkisi" faktöründe yer alan on birinci ve on dördüncü sorularda öğrencilerin sera etkisi ile ilgili kavramları incelemiştir. On birinci soruda, sera etkisinin bir sonucu olan küresel ısınmaya neden olan gazlarla ilgili öğrencilere üç tane gaz (su buharı, karbon dioksit ve azot) verilerek, bunlardan hangisi ya da hangilerinin küresel ısınmaya neden olan gazlardan olmadığı sorulmuştur. Tablo 4'te yer alan bulgular incelendiğinde doğru cevap "su buharı ve azot" un yer aldığı d şıkkının öğrencilerin \%30,2'si tarafından seçildiği görülür. Bu soruya öğrencilerin $\% 46,1^{\prime} i$ "su buharı" cevabını verirken diğer seçeneklerin yüzdesinin \%10'un altında kaldığı görülmektedir. Sera etkisi ile ilgili diğer soru olan on dördüncü soruda, "Sera etkisine en fazla katkısı olan gaz karbon dioksit $\left(\mathrm{CO}_{2}\right)$ gazıdır.", "Dünyanın ortalama sıcaklığının artmasına neden olur.", "Güneş ışınlarının dünyada kalma 
süresi kısalır." ve "Buzulların eriyerek okyanuslar yükselir." şeklinde ifadeler verilerek bu ifadelerden hangilerinin doğru olduğu sorulmuştur. Bu sorunun doğru cevabı "Güneş ışınlarının dünyada kalma süresi kısalır." ifadesinin dışındaki tüm ifadelerin doğru olduğunun belirtildiği şık, öğrencilerin $\% 49,9^{\prime} u$ tarafından seçilmiştir. Diğer şıklara verilen cevaplar incelendiğinde, öğrencilerin bu ifadenin yer aldığı üç şıkkı \%11,6, \%7,8, \%20,9 yüzdelerinde seçtiği belirlenmiştir.

"Gaz kirleticilerin çevreye etkisi" faktöründe yer alan on üçüncü ve on yedinci sorular asit yağmurları teması altında yer alan sorulardır. Bu sorulardan on üçüncü soruya öğrencilerin \%75,3'ü doğru cevap verirken, on yedinci soruya da \%67,7'si doğru cevap vermiştir. On üçüncü soruda öğrencilere asit yağmurlarının zararları ile ilgili, "Yeryüzündeki bitki örtüsüne ciddi zararlar verir.", "Su kaynaklarında asit oranını artırarak suyu kirletir ve sudaki canlı hayata zarar verir.", "Binalarda, tarihi eserde, diğer yapılarda, araçlarda aşınma ve korozyona sebep olur." ve "Toprak yapısını olumsuz etkileyerek toprağı verimsizleştirir." şeklinde dört önemli asit yağmuru zararı ifadesi verilerek hangilerinin doğru olduğu sorulmuştur. Bu soruda verilen bütün ifadeler asit yağmurlarının zararları ile ilgili olup doğru şık dışındaki şıklara verilen cevapların hepsinin \%10'un altında yer aldığı Tablo 4'den görülmektedir. Öğrencilerin asit yağmurlarına neden olan gazlarla ilgili kavramalarını belirlemek amacıyla hazırlanan on yedinci soruda öğrencilere beş tane gaz $\left(\mathrm{H}_{2}, \mathrm{NO}_{2}, \mathrm{O}_{2}, \mathrm{~N}_{2}, \mathrm{CFC}\right)$ formülü verilerek, bunlardan hangisinin asit yağmurlarına neden olduğu sorulmuştur. Bu sorunun doğru cevabı olan "' $\mathrm{NO}_{2}$ " seçeneğinin öğrencilerin \%67,7'si tarafından seçildiği belirlenmiştir. Diğer şıklara verilen cevaplardan sadece e şıkkı dışındaki şıkları seçme oranı \%10'un altında yer almakta olup “CFC" gazının öğrencilerin \%10,7'si tarafından seçildiği Tablo 4'den görülmektedir.

"Gaz kirleticilerin çevreye etkisi" faktörü altındaki on altıncı soruda, öğrencilerin ozon tabakası ile ilgili kavramaları incelenmiştir. Öğrencilere verilen "ozon, metan, azot oksit, kloroflorokarbon ve karbondioksit" maddelerinden hangisinin Dünya'yı güneşin zararlı ışınlarından koruyan tabaka olduğu sorulmuştur. Öğrencilerin \%86'sı "ozon" cevabını verirken, diğer şıkların seçilme yüzdesinin \%5'in altında kaldığı belirlenmiştir. Bu faktörde yer alan yirminci soru gaz kirleticilerle ve yirmi dördüncü soru da gaz kirletici etkisi ile ilgili öğrenci kavramalarının belirlenmesi amacıyla sorulan sorulardır. Bu sorulardan yirminci soruda, öğrencilere gaz kirleticilerinden olan azot oksitler ve etkilerine yönelik üç tane doğru ifade verilmiş ve hangi/hangilerinin doğru olduğunu belirlemeleri istenmiştir. "Genel olarak NOx şeklinde gösterilirler.", "Asit yağmurlarına neden olurlar." ve "Dolaylı sera gazı olarak bilinir." şeklindeki ifadelerin hepsinin yer aldığı doğru seçeneğin öğrencilerin \%57,5'u tarafından seçildiği belirlenmiştir. Diğer şıklardan ilk iki ifade yer alanların doğru olduğunu söyleyen öğrenci oranı \%15, 2 iken, ikinci ve üçüncü ifadeleri doğru kabul eden öğrencilerin oranının \%10,9 olduğu belirlenmiştir. Gaz kirleticilerin etkisi ile ilgili öğrenci kavramalarını inceleyen yirmi dördüncü soruya öğrencilerin \%38,2'si doğru cevap vermiştir. Bu soruda gaz kirletici etkisi ile ortaya çıkan çevre sorunlarına yönelik beş ifade verilerek bunlardan hangisinin yanlış olduğu sorulmuştur. Bu sorunun yanlış ifadesi olan " $\mathrm{O}_{3}$ (ozon) tabakasının kalınlaşması dünyanın ortalama sıcaklığını düşürür." ifadesinin öğrencilerin \%38,2' si tarafından yanlış olduğu belirlenirken, diğer doğru olan "Azot oksit ve kükürt oksitler asit yağmurlarına yol açar." ifadesinin öğrencilerin \%21,9'u, "Hava kirliliğini önlemek için fosil yakıtlar kullanılmamalıdır." ifadesinin öğrencilerin \%13,1'i "Sera etkisi sonucu yeryüzü ısınır, iklim ve bitki örtüsü değişir, buzullar erir." ifadesinin öğrencilerin \%11,9'u ve "Egzoz gazları, orman yangınları, enerji santralleri; baca gazları, hava kirliliğine sebep olan kaynaklardır." ifadesinin öğrencilerin $\% 10,7^{\prime}$ si tarafından yanlış olarak düşünüldüğü Tablo 4'den görülmektedir.

"Gaz kirleticilerin çevreye etkisi" faktörü için ortalama başarı ile faktör de yer alan yedi sorunun $(11,13,14,16,17,20,24)$ tamamına öğrencilerin ne kadarının doğru cevap verdiğine yönelik bir analiz yapılmıştır. Bu analiz sonucunda bu faktöre yönelik ortalama başarının 25 puan üzerinden 16,05 olduğu belirlenirken, 421 öğrenciden $33^{\prime}$ ü yani öğrencilerin \%7,8'i “Gaz kirleticilerin çevreye etkisi" faktöründe yer alan bütün soruları doğru olarak cevapladığı bulunmuştur. 


\section{Dördüncü araştırma sorusuna ait bulgular}

"Doğa ve kimya" ünitesinin öğretimi yapılan öğrencilerin çevre kirliliğinin azaltılması için alınacak önlemleri ne derece kavrayabildiklerine yönelik dördüncü araştırma sorusuna cevap bulabilmek için DKÜBT'nin "kirliliğin azaltılması" faktörü altında yer alan sorulara öğrencilerin verdiği cevaplar analiz edilmiştir. Bu faktör altında yedi soru yer almakta olup bu sorular "su kirliliği, çevre kirliliği, hava kirliliği ve toprak kirliliği" olmak üzere dört tema altında toplanmaktadır. Bu temalarda yer alan soruların analizine ait bulgular Tablo 5' de verilmiştir.

Tablo 5.

10. sınıf öğrencilerinin "kirliliğin azaltılması" ile ilgili sorulara verilen cevapların dağılımı

\begin{tabular}{|c|c|c|c|c|c|c|c|c|c|c|c|c|c|}
\hline \multirow{3}{*}{$\begin{array}{r}\text { Soru } \\
\text { No }\end{array}$} & \multirow{3}{*}{ Soru Teması } & \multicolumn{12}{|l|}{ Şıklar } \\
\hline & & & a & & b & & c & & d & & e & & boş \\
\hline & & $f$ & $\%$ & $f$ & $\%$ & $f$ & $\%$ & $f$ & $\%$ & $f$ & $\%$ & $f$ & $\%$ \\
\hline 3 & Su kirliliği & 33 & 7,8 & 16 & 3,8 & 4 & 1,0 & 341 & 81,0 & 26 & 6,2 & 1 & 0,2 \\
\hline 9 & Su kirliliği & 15 & 3,6 & 347 & 82,4 & 32 & 7,6 & 14 & 3,3 & 12 & 2,9 & 1 & 0,2 \\
\hline 12 & Çevre kirliliği & 22 & 5,2 & 345 & 81,9 & 18 & 4,3 & 13 & 3,1 & 22 & 5,2 & 1 & 0,2 \\
\hline 21 & Hava kirliliği & 22 & 5,2 & 23 & 5,5 & 15 & 3,6 & 332 & 78,9 & 25 & 5,9 & 4 & 1,0 \\
\hline 22 & Çevre kirliliği & 312 & 74,1 & 14 & 3,3 & 24 & 5,7 & 30 & 7,1 & 36 & 8,6 & 4 & 1,0 \\
\hline 23 & Çevre kirliliği & 46 & 10,9 & 51 & 12,1 & 38 & 9,0 & 67 & 15,9 & 196 & 46,6 & 23 & 5,5 \\
\hline 25 & Toprak kirliliği & 55 & 13,1 & 32 & 7,6 & 299 & 71,0 & 15 & 3,6 & 16 & 3,8 & 4 & 1,0 \\
\hline
\end{tabular}

"Kirliliğin azaltılması" faktörü altında yer alan sorulardan üçüncü ve dokuzuncu soru su kirliliğinin önlenmesine yönelik olarak öğrencilerin kavramlarını belirlemek amacıyla sorulmuştur. Üçüncü soruya öğrencilerin \%81'i doğru cevap verirken, dokuzuncu soruya öğrencilerin \%82,4'ü doğru cevap vermiştir. Üçüncü soruda su kirliliğinin önlenmesi ile bazı ifadeler verilerek bunlardan hangilerinin doru olduğu sorulmuştur. Bu ifadelerden "Insanlar su kirliliği konusunda bilinçlendirilmelidir.", "Pet şişeler, plastik torba ve poşetler sulara atılmamalıdır." ve "Sanayi kuruluşları arıtma tesisleri kurmalıdır." şeklindeki ifadeler doğru iken "Deterjanların sulara karışması sağlanmalıdır." ifadesi yanlış bir ifadedir. Öğrencilerin bu ifadenin de yer aldığı, b, c ve d şıklarının her birini \%10'un altında seçtikleri Tablo 5'ten görülmektedir. Su kirliliğinin önlenmesine yönelik hazırlanan dokuzuncu soruda, öğrencilere beş tane ifade verilerek bunlardan hangisinin su kirliliğinin önlenmesi ile ilgili alınacak tedbirlerden biri olmadığı sorulmuştur. Öğrencilerin dokuzuncu soruya verdikleri cevaplar incelendiğinde, \%82,4'ü yerleşim yerlerinin atık suları direkt derelere ve göllere verilmemesi gerektiğinin farkında olduğu görülmüştür. Ancak öğrencilerin \%7,6'sı "Gübre ve tarımsal ilaçların sulara karışması önlenmelidir." ifadesinin, \%3,6'sı "Aşırı deterjan kullanımından kaçınılmalıdır." ifadesinin, \%3,3'ü "Atık su arıtma tesisleri çoğaltılmalıdır." ifadesinin ve \%2,9'u "içme ve kullanma suları dezenfekte edilmelidir." ifadesinin su kirliliğini önlemek için alınacak önlemlerden olmadığını düşündükleri belirlenmiştir.

Tablo 5'te yer alan "kirliliğin azaltılması" faktörü altındaki soru temaları incelendiğinde, on ikinci, yirmi ikinci ve yirmi üçüncü soruların genel anlamda çevre kirliliğinin azaltılmasına yönelik öğrencilerin kavramlarını araştıran sorular oldukları görülür. On ikinci soruya öğrencilerin \%81,9'u, yirmi ikinci soruya $\% 74,1^{\prime} i$ ve yirmi üçüncü soruya $\% 46,6$ 'sı doğru cevap vermiştir. On ikinci soruda öğrencilere çevre ile ilgili bazı ifadeler verilerek, verilen bu ifadelerden hangisinin yapılması durumunda çevreye daha az zarar verileceği sorulmuştur. Bu soruya ait ifadelerden "Plastik, cam, kâğıt, metal gibi atıkların geri dönüşümünün yapılması" şeklindeki doğru ifade öğrencilerin \%81,9'u tarafından seçilmişken, yanlış ifadelerden "Sanayi Kuruluşlarının arttırılması" ifadesi öğrencilerin \%5,2'si, "Işse giderken özel aracın kullanılması" ifadesi öğrencilerin "\%4,3'ü, "Evde yakıt olarak kömür 
kullanılması" ifadesi öğrencilerin \%3,1'i ve "Pillerin çöpe atılması" ifadesi öğrencilerin \%5,2'si tarafından seçilmiştir. Yirmi ikinci soruda öğrencilere, beş adet ifadeden hangisinin çevreye verilen zararlı maddelerin etkilerinin azaltacak önlemlerden birinin olmadığı sorulmuştur. Öğrencilerin \%74,1'i çevreye verilen zararı azaltmayacak doğru ifade olarak "Kâğıt yerine naylon torba tercih edilmesi" ifadesini seçmiştir. Diğer yanlış şıklardan "Plastik, pil vb. atıkların geri dönüşümünün sağlanması." ifadesi öğrencilerin \%3,3'ü tarafından, "Yenilenebilir enerjiye daha fazla önem verilmeli." ifadesini öğrencilerin $\% 5,7$ 'si, "Ozon tabakasına zarar veren gazların kullanımının kısıtlanması." ifadesini öğrencilerin $\% 7,1$ 'i ve "Motorlu taşıtların düzenli olarak egzoz muayenelerinin yaptırılması." ifadesini öğrencilerin $\% 8,6$ 'sı seçmiştir. Yirmi üçüncü soruda etkin mikroorganizmaların (EM) kullanıldığı alanlar ile ilgili öğrencilerin kavramlarını incelemiştir. Bu soru için "Çöplerin organik kısmının kısa sürede gübreleşmesi.", "Sinek, böcek ve zararlı haşaratın azaltılması.", "Kötü kokuların yok edilmesi." ve "Atık suların arıtılması." şeklinde dört ifade verilerek hangilerinin etkin mikroorganizmalar alanlarında kullanıldığı sorulmuştur. Bu sorunun bütün ifadeleri etkin mikroorganizmaların kullanım alanları olduğuna yönelik doğru seçenek öğrencilerin \%46,6'sı tarafından seçilmiştir. Bu şıklardan en az seçilenin "Atık suların arıtılması." olduğu görülmektedir.

"Kirliliğinin azaltılması" faktöründe yer alan sorulardan hava kirliliğinin azalmasına yönelik öğrencilerin kavramalarının incelendiği yirmi birinci soruya ait bulgulara bakıldığında, öğrencilerin \%78,9'unun doğru cevap verdiği görülür. Bu soru için öğrencilere "Ağaçlandırmanın arttırıması.", "Fosil yakıt tüketiminin arttırılması." ve "Fabrika bacalarına filtre takılması" şeklinde üç ifade verilerek, hava kirliliğini azaltmak için bu işlemlerden hangi/hangilerinin yapılması gerektiği sorulmuştur. Doğru seçenek öğrencilerin \%78,9'u tarafından seçilirken, yanlış olan ikinci ifadenin yer aldığı seçeneklerden c şıkkının öğrencilerin \%3,6'sı ve e şıkkının öğrencilerin \%5,9'u tarafından seçildiği belirlenmiştir.

Testin yirmi beşinci sorusunda toprak kirliliğine karşı alınabilecek önlemler ile ilgili öğrencilerin kavramaları incelemiştir. Öğrencilere toprak kirliliğine alınabilecek önlemler olarak beş ifade verilerek bunlardan hangisinin bu önlemlerden biri olmadığının sorulduğu bu soruya öğrencilerin \%71'i “Ambalaj sanayinde plastik kullanımının arttırılması" nın bir önlem olmadığını seçerek doğru cevap vermiş̧ir. Öğrencilerin $\% 13,1$ ' $i$ "Verimli tarım alanlarına sanayi tesisleri kurulmaması." ifadesini, \%7,6'sı "Toprağa bilinçli ilaçlama ve gübreleme yapılması." ifadesini, \%3,6'sı "Evsel atıklar uygun şekilde toplanması ve imha edilmesi." ifadesini ve \%3,8'i "Otlak ve ormanların korunması." ifadesini seçtikleri görülmektedir.

"Kirliliğinin azaltılması" faktörü için ortalama başarı ile faktörde yer alan yedi sorunun $(11,13$, $14,16,17,20,24)$ hepsini öğrencilerin ne kadarının doğru cevap verdiğine yönelik bir analiz yapılmışır. Bu analiz sonucunda bu faktöre yönelik ortalama başarının 25 puan üzerinden 20,71 olduğu belirlenirken, 421 öğrenciden 126 'sı yani öğrencilerin \%29,9'u "kirliliğinin azaltılması" faktöründe yer alan bütün soruları doğru olarak cevapladığı bulunmuştur.

\section{Beşinci araştırma sorusuna ait bulgular}

“Doğa ve kimya" ünitesine yönelik 10. sınıf öğrencilerinin bilgi düzeylerinin nasıl olduğuna yönelik beşinci araştırma sorusuna cevap bulabilmek için yöntem kısmında açıklanan bilgi düzeyi modeli kullanılarak ilgili hesaplamalar yapılmıştır. Her üç düzeyde yer alan öğrencilerin sayısı, yüzde olarak oranları, aritmetik ortalamaları ve standart sapma değerleri Tablo 6'da gösterilmiştir. Ayrıca testin tamamına ait öğrenci başarı ortalaması da tablo da yer almaktadır. 
Tablo 6.

10. sınıf öğrencilerinin "doğa ve kimya” ünitesine yönelik bilgi düzeyi modeli

\begin{tabular}{|c|c|c|c|c|c|c|c|c|c|c|c|c|c|}
\hline \multicolumn{12}{|c|}{ Bilgi düzeyi } & \multirow{2}{*}{\multicolumn{2}{|c|}{ Toplam }} \\
\hline \multicolumn{4}{|c|}{ Düşük } & \multicolumn{4}{|c|}{ Orta } & \multicolumn{4}{|c|}{ Yüksek } & & \\
\hline$f$ & $\%$ & $\bar{X}$ & $S$ & $f$ & $\%$ & $\bar{X}$ & $S$ & $f$ & $\%$ & $\bar{X}$ & $S$ & $\bar{X}$ & $s$ \\
\hline 52 & 12,4 & 20,92 & 6,93 & 120 & 28,5 & 53,63 & 8,97 & 249 & 59,1 & 82,28 & 8,92 & 66,54 & 22,97 \\
\hline
\end{tabular}

Tablo 6 incelendiğinde 0-33 puan aralığında 52 (\%12,4), 34-67 puan aralığında 120 (\%28,5), 68-100 puan aralığında ise sadece $249(\% 59,1)$ 10. sınıf öğrencisi bulunduğu görülmektedir. Öğrencilerin aldıkları toplam puanın ortalaması $\bar{X}=66,54$ ve standart sapması $S=22,97$ olarak hesaplanmıştır. Bu değer orta düzeyde bilgi düzeyine karşılık gelmektedir. Diğer taraftan her bir düzeye ait yüzdelere bakıldığında öğrencilerin yarısından fazlası \%59'unun ortalamasının 82,28 olduğu yani "doğa ve kimya” ünitesine yönelik bilgi düzeyinin yüksek olduğu görülmektedir.

\section{Tartışma, Sonuç ve Öneriler}

10. sınıf öğrencilerinin "doğa ve kimya" ünitesinin öğretiminden sonra, suyun hayat için önemi, su ve toprak kirliliği, gaz kirleticileri ve çevre kirliliğinin azaltılmasına yönelik alınacak önemler ile ilgili kavramalarının ve çevre bilgi düzeylerinin belirlenmesinin amaçlandığı çalışma sonunda aşağıdaki sonuçlara ulaşılmıştır.

Suyun hayat için önemine yönelik bulgular kısmında, altı temadan "suyun önemi" ile "su tasarrufu" temaları altındaki sorulara verilen doğru cevap oranının \%84'ün ve su kaynakları teması altındaki sorulara verilen doğru cevapların da \%75'in biraz üzerinde olması bu üç konunun öğrenciler tarafından oldukça iyi kavrandığını göstermektedir. Bu kısımdaki diğer üç temadan "yumuşak su", "suyun özellikleri" ve "endüstride su kullanımı" teması altındaki sorulara verilen doğru cevapların yaklaşık \%50 olduğu sonucuna ulaşımıştır. Bu durum öğrencilerin daha teknik bilgi isteyen ve bilgilerini kullanımlarını gerektiren sorularda kavramalarının daha düşük olduğu şeklinde yorumlanabilir. Çalışmada, suyun hayat için önemine yönelik ortalama başarının orta seviyede olduğu sonucuna ulaşılmıştır. Suyun hayatımızdaki yeri ile ilişkilendirildiği bir çalışmada Akgün, Tokur ve Duruk (2016), öğrencilerin sert su, yumuşak su, kalsiyum-magnezyum-sodyum iyonları, suyun arıtımı, klorlama, dezenfeksiyon gibi konuya ilişkin temel kavramları kullanarak günlük yaşamda karşılaştıkları durumları açıklamada yetersiz kaldıklarını belirlemişlerdir.

Su ve toprak kirliliğine yönelik bulgular kısmında, "su kirliliği", "su-toprak kirliliği" ve "toprak kirliliği" şeklindeki üç tema altında toplanan tüm sorulara yönelik öğrenci cevap ortalamalarının $\% 70$ 'in üzerinde olduğu belirlenmiştir. Cevaplar incelendiğinde, öğrencilerin yaklaşık \%80'inin piller, plastikler, deterjanlar ve ağır metaller gibi maddelerin su ve toprak kirliliğine neden olduğunu anladıkları ve yine $\% 75$ inin toprakta uzun süre bozunmadan kalan maddeleri farklandırabildikleri sonucuna ulaşılmıştır. Ayrıca su ve toprak kirliliğine yönelik ortalama başarı değerinin yüksek seviyede olduğu belirlenmiştir. Bu bulgulardan yola çıkarak öğrencilerin su ve toprak kirliliği ile ilgili kavramalarının yüksek olduğu söylenebilir.

Gaz kirleticilerin çevreye etkisine yönelik bulgular kısmında, beş tema altında toplanan sorulardan "sera etkisi" ile ilgili iki soruya verilen doğru cevap yüzdelerinin $\% 30$ ve $\% 45$ civarında yer aldığı belirlenmiştir. Bu durum öğrencilerin sera etkisi ile kavramalarının düşük olduğunu göstermektedir. Jeffries, Stanisstreet ve Boyes (2001) tarafından gerçekleştirilen bir çalışmada, birinci sınıf biyoloji öğrencilerinin küresel ısınma, küresel ısınmanın neden ve sonuçlarına yönelik 
düşünceleri incelenmiştir. Araştırma sonuçları, öğrencilerin küresel ısınma hakkında yeterli bilgi düzeyine sahip olmadığını ve bazı yanlış kavramalara sahip olduklarını ortaya koymuştur

Çalışmada sera etkisine yönelik ulaşılan diğer bir sonuç, öğrencilerin yaklaşık yarısının "azot" gazının küresel ısınmaya neden olan gazlardan biri olarak düşündüğünün belirlenmesidir. Bu durum öğrencilerin küresel ısınmaya neden olan gazları tam olarak kavramadıklarını ve asit yağmurlarına neden olan gazlarla sera etkisine neden olan gazları tam ayırt edemediklerini göstermektedir. Bunun yanında çalışmada alanyazından farklı olarak sera etkisine yönelik bir yanlış kavrama belirlenmiştir. Sera etkisine yönelik yapılan yanlış kavrama çalışmaları incelendiğinde, yanlış kavrama olarak verilen ifadelerden bir kısmının aslında yanlış kavramadan çok bilgi eksikliği olduğu görülür. Genel olarak birçok yanlış kavrama çalışmasında yapılan bu hata ne yazık ki sera etkisi ile ilgili konuda da görülmektedir. Ünlü, Sever ve Akpınar (2011) tarafından gerçekleştirilen Türkiye'de çevre eğitimi alanında yapılmış küresel ısınma ve sera etkisi konulu akademik araştırmaların sonuçlarının incelendiği çalışmada örnek olarak yer alan yanlış kavrama ifadelerinden bir kısmının aslında bilgi eksikliği ifadesi olduğu görülür. Örneğin "Atmosferdeki $\mathrm{CO}_{2}$ miktarının artması, sera etkisine neden olmaz." ifadesi bir yanlış kavrama ifadesinden çok bir bilgi eksikliğidir. Bu nedenle yürütülen bu çalışmada, "öğrencilerin olayı mantıklı bir şekilde açıklamaları için bilimsel anlamda doğru ifadeye alternatif olarak geliştirdikleri ifadeler" yanlış kavrama olarak etiketlenmiştir (Nakiboğlu, 2006). Bu doğrultuda bu çalışmada araştırmacılar tarafından belirlenen yanlış kavrama "sera etkisi nedeniyle güneş ışınlarının dünyada kalma süresinin kısalması" şeklindedir.

"Asit yağmurları" teması ile ilgili sorulan iki sorudan birinde öğrencilerin \%75 ve diğerinde yaklaşık \%68 doğru cevap verilmesi öğrencilerin asit yağmurları ile ilgili kavramalarının yüksek olduğunu göstermektedir. Her ne kadar öğrencilerin yaklaşık \%90'unun ozon tabakasının ne olduğunu kavradıkları belirlenmişse de, bu sorudaki kavrama düzeyinin yüksek olması, konunun güncel olması ve basın ayın organlarında çok sık dile getirilmesinin de etkisi olabileceğini düşündürmektedir. Diğer taraftan bu sorularda seçilen yanlış şıklar incelendiğinde, öğrencilerin sadece asit yağmuruna neden olan gazlarla ozon tabakasına zarar veren gazları birbirine karıştırdıkları sonucuna da ulaşılmıştır. Bu durumun öğrencilerin gazların kimyasal formüllerini tam bilmemelerinden ya da hava kirliliğine neden olan azot oksit, kükürt oksit, karbon dioksit gibi gazları tanımamalarından kaynaklanabilir. Benzer yorumun Ayvacı ve Çoruhlu (2009) tarafından kendi çalışmalarının sonuçlarına bağlı olarak yapıldığı görülmektedir. Yazarlar, ilköğretim ve ortaöğretim düzeyindeki tüm öğrencilerin ozon tabakasının incelmesine neden olan olaylar ile asit yağmurlarının oluşmasına ve sera etkisinin artmasına sebep olan olayları birbirlerinden tam olarak ayıramadıklarına bağlamışlardır. Gambro ve Switzky (1996), Amerikalı 10. ve 12. sınıf öğrencileri ile yürüttüğü çalışmada da benzer sonuçlara ulaşımıştır. Öğrencilerin fabrika bacalarından çıkan kükürt dumanının asit yağmuruna neden olmasına yönelik soruda başarılarının \%70 olduğu görülürken, metal sülfürlerinin asit yağmuruna neden olmasına yönelik soruya yönelik başarının yaklaşık \%40 civarında olduğu belirlenmiştir. Yılmaz ve diğerleri (2002) ortaöğretim ve üniversite öğrencileri ile yürüttükleri çalışmada, kimya öğretmenliği öğrencilerinin genel olarak çöp, geri dönüşüm gibi kavramlara hâkim olmakla beraber, asit yağmuru, sera etkisi, ozon tabakasına zarar veren gazlar gibi konularda başarılarının düşük olduğu sonucuna ulaşmışlardır.

Çevre kirliliğinin azaltılması için alınacak önlemlere yönelik öğrenci kavramaları incelendiğinde, 4 tema altında toplanan sorulardan, "su kirliliği" teması altında yer alan iki soruya $\% 80$ 'in biraz üzerinde öğrencinin doğru cevap verilmesi, su kirliliğinin önlenmesine yönelik öğrencilerin kavramlarının oldukça yüksek olduğunu göstermektedir. "Çevre kirliliği" ile ilgili öğrenci kavramalarına bakıldığında, öğrencilerin çevre kirliliğinin önlenmesi ile ilgili üç sorudan ikisinde doğru cevap yüzdeleri oldukça yüksek (yaklaşık \%82 ve \%74) olduğu belirlenirken üçüncü soruda \%50'nin altında olduğu görülmüştür. Bu üç sorunun içeriği incelendiğinde, başarı yüzdesinin yüksek olduğu soruların günlük hayatla ilişkili ifadelerden oluştuğu görülürken, başarının düşük olduğu sorunun 
etkin mikroorganizmalar ile ilgili daha teknik bilgi gerektirdiği belirlenmiştir. Bu sonucun öğrencilerin güncel konulara yönelik ve basın yayın organlarında daha fazla duyulan konularda daha başarılı olması ile ilgili olduğu söylenebilir. Hava kirliliğinin azalmasına yönelik öğrencilerin kavramalarının yaklaşık \%80 olduğu ve öğrencilerin hava kirliliğini önlemek için ağaçlandırma yapılması, fosil yakıt tüketiminin azaltılması ve fabrika bacalarına filtre takılması gibi önlemleri iyi kavradıklarını göstermektedir. Benzer şekilde, toprak kirliliğine alınacak önlemler konusunda da öğrenci kavramalarına bakıldığında öğrencilerin önemli bir kısmının (\%71), toprak kirliliğine alınacak önlemleri kavradıklarını ortaya koymaktadır. Benzer bir sonuca Yılmaz ve diğerleri (2002) çalışmalarında da ulaşılmıştır. Yazarlar, çevre kirliliğinin azaltılması ile ilgili günlük hayattaki örneklerin yer aldığı soruda öğrencilerin doğru cevap oranını \%80 üzerinde olduğunu belirlemişlerdir.

Su ve toprak kirliliğinin kavramasına yönelik öğrencilerin doğru cevap verme oranlarının gaz kirleticilerinkinden daha yüksek olması, su ve toprak kirliliğine neden olan evsel atıklar, katı veya sıvı atıklar gibi maddeler öğrenciler tarafından etraflarında rahatça gözleyebilecek durumlar olmaları ile de ilişkilendirilebilir. Bir gölün kirli olması ya da yerlerde olan çöplerin insanların rahatça gözlemleyeceği ve onları rahatsız eden durumlar olmaları nedeniyle öğrencilerin su ve toprak kirliliğinin azaltılmasına yönelik farkındalı̆̆ın daha yüksek olmasına neden olur. Diğer taraftan, gaz kirleticilerinin neden olduğu sera etkisi ve buna neden olan sera gazlarının etkilerinin oluşturduğu sonuçlar su ve toprak kirliliğine göre doğrudan gözlenmesi daha güç olan durumlardır.

Sonuç olarak, çevre sorunlarının çözümü için geliştirilen çözüm yollarından en etkili olanı insanların bu sorunlar hakkında bilinçlendirilmesi olacağı açıktır. Bunun sağlanması toplumun her kesimini kapsayan nitelikli bir çevre eğitimiyle mümkün olabilir. Çevre eğitiminin önemli bir amacı, toplumda çevre sorunlarının bilincinde olan çevre okuryazarı bireylerin yer almasının sağlanmasıdır (Kışoğlu ve diğ., 2010). Çevre sorunlarına karşı toplumda yaşayan bireylerin üzerlerine düşen görev ve sorumlulukları yerine getirmeleri de, yine bireylere verilecek çevre eğitimiyle mümkün olacaktır (Soran, Morgil, Atav, Işık, 2000). Yapılan çalışmalarda, ülkemizde istenilen düzeyde bir çevre eğitiminin verilmediğine işaret edilmiştir (Ünal ve Dımışkı, 1999; Kahyaoğlu ve Kaya, 2012). Çalışmadan elde edilen sonuçlardan da yola çıkarak, çevre eğitimi ile ilgili konuların ortaöğretimde kimya veya biyoloji derslerinde birer ünite olmasının yanın da ayrı bir ders olarak ortaöğretim programında yer alması önerilebilir. Ayrıca çevre dersi içeriğinin sadece biyoloji veya sadece kimya ağılıklı olmaması ve her iki alana da dayanan teorik bilgilerin öğrencilere öğretilmesi gerekir. Bu durum başka araştırmalarda da dile getirilmiş olup, çevre eğitiminin disiplinler arası bir yaklaşımla ele alması ve bu sürecin okul öncesinden yükseköğretime kadar tüm örgün ve yaygın eğitim durumlarında devam etmesi gerektiği vurgulanmıştır (Ünal ve Dımışkı, 1999). Çevre dersinde teorik bilgilerin öğretiminden sonra mutlaka evrensel çevre sorunları ve bunlara yönelik çözümler konusunda öğrencinin aktif katılımının sağlanacağı öğretimin yapılması da gerekmektedir.

Bu çalışmada ele alınan "doğa ve kimya” ünitesi kapsamında konunun öğretimine yönelik özel bir öneri olarak, bu ünitenin öğretiminde yaşam temelli öğrenme yaklaşımının yer aldığı bir tasarım ile verilmesi öğrencinin öğrenmesine önemli katkı sağlayabilir. Çalışmada, öğrenci kavramalarının özellikle ünitenin günlük hayatla doğrudan ilişkili sorular için yüksek çıkması, bu öneriyi destekler niteliktedir. "doğa ve kimya" ünitenin içeriği, 2013 yılı Kimya dersi öğretim programındaki "hayatımızdaki kimya" ünite içeriğine benzemektedir. Kutu ve Sözbilir (2011) "hayatımızdaki kimya" ünitesinin öğretiminde Yaşam Temelli ARCS Öğretim Modelinin ortaöğretim kimya öğretiminde uygulanabilirliğini incelemiş ve çalışma sonunda kullanılan yöntemin öğrenmenin kalıcılığını ve öğrencilerin motivasyonlarını artırdığını sonucuna ulaşmışlardır. Bu nedenle "doğa ve kimya" ünitesi kapsamında konunun öğretiminde yaşam temelli öğrenme gibi öğrenci merkezli öğretime yer verilmesi son derece önemlidir. 


\section{Kaynakça}

Akgün, A., Tokur, F. ve Duruk, Ü. (2016). Fen Öğretiminde Öğrenilen Kavramların Günlük Yaşamla iliş̧kilendirilmesi: Su Kimyası ve Su Arıtımı. Adıyaman Üniversitesi Eğitim Bilimleri Dergisi, 6(1), 161 178. Doi: $10.17984 / a d y u e b d .87973$

Akyol, B. ve Kahyalıŏlu, H. (2012). İlköğretim öğrencilerinin çevre bilgi düzeyleri üzerine bir çalışma (Niğde Örneği), X. Ulusal Fen Bilimleri ve Matematik Eğitimi Kongresi Bildiri Özetleri Kitabı, 27-30 Haziran. Niğde: Pegem Akademi, 53.

Arsal, Z. (2010). Illköğretim öğretmen adaylarının sera etkisi ile ilgili kavram yanılgılarının belirlenmesi. Illköğretim Online, 9(1), 229-240.

Atasoy E. ve Ertürk, H. (2008). İlköğretim öğrencilerinin çevresel tutum ve çevre bilgisi üzerine bir alan araştırması. Erzincan Eğitim Fakültesi Dergisi, 10(1), 105-122.

Ayvacı, H. Ş. ve Şenel Çoruhlu, T. (2009). Öğrencilerin küresel çevre sorunlarına bakışları ve kavram yanılgılarının belirlenmesine yönelik gelişimsel bir araştırma. Hasan Ali Yücel Eğitim Fakültesi Dergisi, 12(2), 11-25.

Bahar, M. ve Aydın, F. (2002). Sınıf öğretmenliği öğrencilerinin sera gazları ve global ısınma ile ilgili anlama düzeyleri ve hatalı kavramları. V. Ulusal Fen Bilimleri ve Matematik Eğitimi Kongresi'nde sunulan bildiri. Eylül 2002, ODTÜ, Ankara.

Bakırcı, H. ve Yıldırım, í. (2017). Ortak bilgi yapılandırma modelinin sera etkisi konusunda öğrencilerin kavramsal anlamalarına ve bilginin kalıcılığına etkisi. Ahi Evran Üniversitesi Kırşehir Eğitim Fakültesi Dergisi, 11(18), 45-63.

Başaran Uğur, A. R., Bektaş, O., \& Güneri, E., (2019). Sınıf ve fen bilgisi öğretmen adaylarının sürdürülebilir çevre tutum düzeyleri. Uluslararası Sosyal Araştırmalar Dergisi. 12(63), 775-788. Doi:10.17719/jisr.2019.3275

Boyes, E. ve Stanisstreet, M. (1998). High school students' perceptions of how major global environmental effects might cause skin cancer. Journal of Environmental Education, 29(2), 31-36. Doi:10.1080/00958969809599110

Bozkurt, O. ve Cansüngü Koray, Ö. (2002). İlköğretim öğrencilerinin çevre eğitiminde sera etkisi ile ilgili kavram yanılgıları. Hacettepe Üniversitesi Eğitim Fakültesi Dergisi, 23, 67-73.

Büyüköztürk, Ş., Kılıç Çakmak, E., Akgün, Ö.E., Karadeniz, Ş. ve Demirel, F. (2017). Bilimsel Araştırma Yöntemleri (23. Baskı). Ankara: Pegem Akademi Yayıncılık.

Demircioğlu, G., Demircioğlu, H. ve Yadigaroğlu, M. (2015). Fizik, kimya ve biyoloji öğretmen adaylarının çevre bilinç düzeylerinin değerlendirilmesi. Adıyaman Üniversitesi Sosyal Bilimler Enstitüsü Dergisi, 8(19), 167-193. Doi:10.14520/adyusbd.41708

Frick, J., Kaiser, F. G. ve Wilson, M. (2004). Environmental knowledge and conservation behavior: Exploring prevalence and structure in a representative sample. Personality ve Individual Differences, 37(8), 1597-1613. Doi: 10.1016/j.paid.2004.02.015

Gambro, J. S. ve Switzky, H. N. (1996). A National survey of high school students' environmental knowledge. The Journal of Environmental Education, 27(3), 28-33. Doi:10.1080/00958964.1996.9941464

Güneş Yazar, O. ve Nakiboğlu, C. (2019). 9. sınıf “doğa ve kimya” ünitesi ile ilgili başarı testi geliştirilmesi: geçerlilik ve güvenirlik çalışması. Necatibey Eğitim Fakültesi Elektronik Fen ve Matematik Eğitimi Dergisi, 13(1), 76-104.

Güven, E. (2013). Çevre sorunları başarı testinin geliştirilmesi ve öğretmen adaylarının bilgi düzeylerinin belirlenmesi. Trakya Üniversitesi Eğitim Fakültesi Dergisi 3(2), 114-127.

Hungerford, H. ve Volk, T. (1990). Changing learner behavior through environmental education. The Journal of Environmental Education 21(3), 8-21. Doi: 10.1080/00958964.1990.10753743

Jeffries, H., Stanisstreet, M. ve Boyes, E. (2001). Knowledge about the "greenhouse effect": have college students improved? Research in Science and Technology Education, 19(2), 205-221. Doi: 10.1080/02635140120087731

Kaplowitz, M. ve Levine, R. (2005). How environmental knowledge measures up at a big ten university. Environmental Education Research, 11(2), 143-160. Doi: 10.1080/1350462042000338324

Kahyaoğlu, M. ve Kaya, M.F. (2012). Öğretmen adaylarının çevre kirliliğine ve çevreyle ilgili sivil toplum örgütlerine yönelik görüşleri. Eğitim Bilimleri Araştırmaları Dergisi Uluslararası e-dergi, 2(1), 91-107.

Kınay, A., Stanisstreet, M. ve Boyes, E. (2008). Turkish Students' ideas about global warming. International Journal of Environmental \& Science Education, 3(2), 89 - 98. 
Kışoğlu, M., Gürbüz, H., Sülün, A., Alaş, A. ve Erkol, M. (2010). Çevre okuryazarlığı ve çevre okuryazarlığı ile ilgili Türkiye'de yapılan çalışmaların değerlendirilmesi. International Online Journal of Educational Sciences, 2(3), 772-791.

Kutu, H. ve Sözbilir, M. (2011). Yaşam temelli ARCS öğretim modeliyle 9. sınıf kimya dersi "Hayatımızda Kimya” ünitesinin öğretimi. Ondokuz Mayıs Üniversitesi Eğitim Fakültesi Dergisi, 30(1), 29-62.

Leeming, F. C., Dwyer, W. O. ve Bracken, B. A. (1995). “Children's environmental attitude and knowledge scale: Construction and validation." The Journal of Environmental Education, 26(3): 22-31. Doi:10.1080/00958964.1995.9941442

Liu, W. ve Chen, J. (2019). Modified two major environmental values scale for measuring Chinese children's environmental attitudes. Environmental Education Research, 1-18. Doi:10.1080/13504622.2019.1697431

McBeth, W., Hungerford, H., Marcinkowski, T., Volk, T. ve Meyers, R. (2008). National environmental literacy asessment project: Year 1, National baseline study of middle grade students; final research report. Unpublished Project Report. Florida Institute of Technology, Melbourne, USA.

Nakiboğlu, C. (2006). Fen ve Teknoloji Öğretiminde Yanlış Kavramalar. M. Bahar (Ed.). Fen ve Teknoloji Öğretimi, (191-217).(1. Baskı).Ankara: Pegem A Yayıncılık.

Österlind, K. (2005). Concept formation in environmental education: 14-year olds' work on the intensified greenhouse effect and the depletion of the ozone layer. International Journal of Science Education, 27(8), 891-908. doi:10.1080/09500690500038264

Palmer, J. A. (2003) Environmental education in the 21st century: Theory, practice, progress and promise. UK, London: Routledge.

Pe'er, S., Goldman, D. ve Yavetz, B. (2007). Environmental literacy in teacher training: attitudes, knowledge, and environmental behavior of beginning students. The Journal of Environmental Education, 39(1), 45-59. Doi:10.3200/JOEE.39.1.45-59

Sadık, F. ve Çakan, H. (2010). Biyoloji bölümü öğrencilerinin çevre bilgisi ve çevre sorunlarına yönelik tutum düzeyleri. Ç.Ü. Sosyal Bilimler Enstitüsü Dergisi, 19(1), 351-365.

Soran, H., Morgil, F., Yücel, S., Atav, E. ve Işık, S. (2000). Biyoloji öğrencilerinin çevre konularına olan ilgilerinin araştırılması ve kimya öğrencileri ile karşılaştırılması. Hacettepe Üniversitesi Eğitim Fakültesi Dergisi, $18,128-139$.

Timur, S. ve Yılmaz, M. (2011). Fen Bilgisi öğretmen adaylarının çevre bilgi düzeylerinin belirlenmesi ve bazı değişkenlere göre incelenmesi. Gazi Eğitim Fakültesi Dergisi, 31(1), 303-320.

Ünal, S. ve Dımışkı, E. (1999). UNESCO-UNEP himayesinde çevre eğitiminin gelişimi ve Türkiye'de ortaöğretim çevre eğitimi. Hacettepe Üniversitesi Eğitim Fakültesi Dergisi 16(17), 142 - 15.

Ünlü, İ., Sever, R. ve Akpınar, E. (2011). Türkiye'de çevre eğitimi alanında yapılmış küresel ısınma ve sera etkisi konulu akademik araştırmaları sonuçlarının incelenmesi. Erzincan Eğitim Fakültesi Dergisi, 13(1), 39 54.

Yılmaz, A., Morgil, I, Aktuğ, P. ve Göbekli, i. (2002). Ortaöğretim ve üniversite öğrencilerinin çevre, çevre kavramları ve sorunları konusundaki bilgileri ve öneriler. Hacettepe Üniversitesi Eğitim Fakültesi Dergisi, 22, 156-162. 